CZU 338.5

https://doi.org/10.52507/2345-1106.2021-2.15

STABILITATEA PREȚURILOR - OBIECTIV MACROECONOMIC MAJOR

DUHLICHER Grigore,

Dr. în științe economice, lector universitar, Universitatea de Studii Europene din Moldova https://orcid.org/0000-0002-1159-0830

\title{
REZUMAT
}

Prețul reprezintă un element de bază al sistemului economiei de piață şi a devenit o categorie economică de prim rang, datorită funcțiilor sale în cadrul acesteia. Asigurarea stabilității prețurilor constituie un obiectiv major al procesului de guvernare, deoarece contribuie la crearea unui cadru economic relativ stabil care permite dezvoltarea economică şi asigurarea unui nivel susținut al creșterii economice. Crizele economice mondiale, în paralel cu instabilitatea politică regională, agravate și de consecințele devastatoare ale situației pandemice, accentuează încă o dată importanța dinamicii evoluției prețurilor asupra situațiilor macroeconomice ale statelor contemporane.

Cuvinte-cheie: preț, stabilitatea prețurilor, inflație.

\section{PRICE STABILITY - MAJOR MACROECONOMIC OBJECTIVE}

DUHLICHER Grigore,

$\mathrm{PhD}$ in Economics, University lecturer, University of European Studies of Moldova https://orcid.org/0000-0002-1159-0830 


\section{SUMMARY}

Price is a basic element of the market economy system and has become a leading economic category, due to its functions within it. Ensuring price stability is a major objective of the governance process, as it contributes to creating a relatively stable economic framework that allows for economic development and ensuring a sustained level of economic growth. The global economic crises, in parallel with the regional political instability, aggravated by the devastating consequences of the pandemic situation, emphasize once again the importance of the dynamics of price developments on the macroeconomic situations of contemporary states.

Key words: price, price stability, inflation.

Introducere. Prețul, pe de o parte, desemnează un concept economic multidimensional, care stă la temelia economiei de schimb, iar pe de altă parte, reprezintă un instrument al pieței, un indicator de bază al realității social-economice.

În cadrul economiei de piață, prețurile mărfurilor și serviciilor se pot modifica oricând. Unele prețuri cresc, altele scad. Inflaţia se manifestă în cazul în care se înregistrează o creștere generalizată a prețurilor bunurilor și serviciilor, nu doar ale unor articole specifice, ceea ce înseamnă că puterea de cumpărare a monedei din circulație se micşorează.

Cercetările teoretice și practica economică ne demonstrează că stabilitatea prețurilor contribuie semnificativ la bunăstarea generală, inclusiv la expansiunea activității economice și la creșterea gradului de ocupare a forței de muncă.

Rezultate și discuții. Stabilitatea macroeconomică reprezintă scopul principal al procesului de guvernare. În această ordine de idei, stabilitatea prețurilor poate fi considerată un criteriu de bază ce poate fi utilizat în aprecierea eficienței actului de guvernare.

Având în vedere recunoașterea pe scară largă a beneficiilor stabilității prețurilor, este important să înțelegem importanța stabilității prețurilor, modul optim de realizare a acesteia și cum anume favorizează menținerea acesteia realizarea obiectivelor economice generale ale procesului de guvernare.

Importantă în acest sens este aprecierea corectă și reală a situaţiei macroeconomice. Respectiv, pot fi utilizați indicii statistici care dau concretețe analizei respective, deoarece reprezintă structuri, reprezintă evoluții, reprezintă modificări în timp și spaţiu a fenomenului cercetat.

Este important să se facă distincția între variațiile prețurilor oricăror bunuri sau servicii considerate individual și cele ale nivelului general al prețurilor. Modificările frecvente ale prețurilor individuale sunt relativ normale în economiile de piață, chiar şi atunci când preturile sunt stabile în ansamblu.

În cadrul Republicii Moldova, informaţii referitoare la dinamica prețurilor, sunt oferite de Biroul Național de Statistică, care utilizează în acest sens următorii indicatori [1]:
* Indicele prețurilor de consum (IPC) - este un indicator economic, care măsoară evoluția de ansamblu a prețurilor mărfurilor cumpărate și a tarifelor serviciilor utilizate de către populație între două perioade (curentă și de bază).

* Rata lunară a inflației - reprezintă creșterea prețurilor de consum într-o lună față de luna precedentă.

* Rata medie lunară a inflației - exprimă media creșterilor lunare ale prețurilor. Se calculează ca medie geometrică a indicilor lunari ai prețurilor de consum cu bază în lanț din care se scade baza de comparație egală cu 100.

* Rata anuală a inflației - reprezintă creșterea prețurilor de consum într-o lună din anul curent, față de aceeași lună a anului precedent. Se calculează ca un raport exprimat procentual, între indicele prețurilor de consum dintr-o lună din anul curent și indicele din luna corespunzătoare a anului precedent, calculat față de aceeași bază, din care se scade 100 .

* Rata medie anuală a inflației - reprezintă creșterea medie a prețurilor de consum într-un an, față de anul precedent. Se calculează ca un raport, exprimat procentual, între indicele mediu al prețurilor de consum dintr-un an și cel al anului precedent, din care se scade 100.

* Rata inflației la sfârșitul anului reprezintă creșterea preturilor de consum în luna decembrie a unui an față de aceeași lună a anului precedent. În luna decembrie a fiecărui an, rata inflației la sfârșitul anului coincide cu rata anuală a inflației.

Indicele preturilor de consum măsoară evoluția de ansamblu a prețurilor mărfurilor cumpărate și a tarifelor serviciilor utilizate de către populație într-o anumită perioadă de timp, față de cea precedent, sau una de referință.

Indicele prețurilor de consum se calculează numai pentru elementele care intră în consumul direct al populației, fiind excluse: consumul din resurse proprii, cheltuielile cu caracter de investiții şi acumulare, dobânzile plătite la credite, ratele de asigurare, amenzile, impozitele etc., precum și cheltuielile aferente plății muncii pentru producția agricolă a gospodăriilor individuale.

Tabelul 1. Rata inflației în luna August, înregistrată în Republica Moldova

\begin{tabular}{|l|c|c|c|c|c|c|c|}
\hline \multirow{2}{*}{$\begin{array}{c}\text { Mărfuri și } \\
\text { servicii }\end{array}$} & $\begin{array}{c}\text { Coeficientul } \\
\text { de ponderație }\end{array}$ & \multicolumn{3}{|c|}{ August 2021, în \% față de } & \multicolumn{3}{|c|}{ August 2020, în \% față de } \\
\cline { 3 - 8 } & $\begin{array}{c}\text { (în } \\
\text { decimile) }\end{array}$ & 2021 & $\begin{array}{c}\text { Iulie } \\
\text { Tecembrie }\end{array}$ & $\begin{array}{c}\text { August } \\
2020\end{array}$ & $\begin{array}{c}\text { Iulie } \\
2020\end{array}$ & $\begin{array}{c}\text { Decembrie } \\
2019\end{array}$ & $\begin{array}{c}\text { August } \\
2019\end{array}$ \\
\hline Total & 10000 & 0,33 & 4,29 & 4,64 & - & 0,05 & 3,45 \\
\hline
\end{tabular}




\begin{tabular}{|c|c|r|r|r|r|r|r|}
\hline & & & & & 0,78 & & \\
\hline $\begin{array}{c}\text { Produse } \\
\text { alimentare }\end{array}$ & 3634,29 & - & 4,27 & 4,83 & - & 1,11 & 7,59 \\
\hline $\begin{array}{c}\text { Mărfuri } \\
\text { nealimentare }\end{array}$ & 3784,65 & 1,01 & 5,98 & 6,93 & - & $-1,37$ & $-0,04$ \\
\hline Servicii & 2581,06 & 0,53 & 1,82 & 1,02 & - & 0,30 & 2,13 \\
\hline
\end{tabular}

Sursa: https://statistica.gov.md/newsview.php?l=ro\&idc=168\&id=7120

Din informațiile prezentate în tabelul 1, observăm că preturile medii de consum în luna august 2021 față de luna iulie 2021 au crescut cu $0,33 \%$. Ca comparație, în luna august 2020 față de iulie 2020 acestea au înregistrat o scădere de $0,78 \%$. Creșterea prețurilor medii de consum a fost determinată de majorarea prețurilor la mărfurile nealimentare cu $1,01 \%$ și la serviciile prestate populației cu $0,53 \%$. Totodată, prețurile de consum la produsele alimentare în luna august 2021 față de luna iulie 2021 sau diminuat cu $0,53 \%$.

De asemenea, din informațiile oferite de Biroul Național de Statistică observăm că, prețurile medii de consum în luna august 2021 comparativ cu luna august 2020 au crescut cu 4,64\%, inclusiv la produse alimentare cu 4,83\%, mărfuri nealimentare cu $6,93 \%$ și serviciile prestate populației cu $1,02 \%$.

Pentru a ne crea o imagine mai clară, vom examina situația legată de dinamica prețurilor de consum în Republica Moldova, în context regional, prezentând și informații referitoare la acest fenomen în România.

Evoluția prețurilor bunurilor și serviciilor de consum în România, în luna august 2021 faţă de luna august 2020 a înregistrat următoarele nivele [2]:

- Rata inflației în august 2021 comparativ cu aceeași lună a anului 2020 a fost 5,3\% în România, față de 4,64 în Republica Moldova;

- Preturile mărfurilor alimentare au crescut cu 2,7\% în România, față de 4,83 în Republica Moldova;

- Prețurile mărfurilor nealimentare au fost mai mari cu 7,9\% în România, față de 6,93 în Republica Moldova;

- Tarifele serviciilor s-au mărit cu 3,0\% în România, față de 1,02 în Republica Moldova.

Pe parcursul perioadei analizate, presiuni inflaționiste au fost determinate de creșterea prețurilor la petrol care a generat accelerarea prețurilor la combustibili pe piața internă.

În acelaşi timp, recolta modestă pentru anumite culturi din anul precedent, majorarea prețurilor de import şi intensificarea presiunilor din partea costurilor au susținut majorarea prețurilor la produsele alimentare pe piaţa locală și un impact mai pronunțat din partea acestora asupra ratei anuale a Indicelui Prețurilor de Consum.

Creșterea prețurilor unor materii prime și dinamica ratei de schimb au determinat majorarea prețurilor unor subcomponente aferente inflației de baza. Presiunile din partea ofertei sunt alimentate și de cererea agregata internă din perspectiva recuperării consumului populației pe fondul accelerării fondului de salarizare, volumului creditelor noi acordate, transferurilor de mijloace bănești în favoarea persoanelor fizice [3].

Este necesar de menționat și faptul că evoluția prețurilor de consum în cadrul pieței interne a Republicii
Moldova, trebuie analizată și în context internațional. Astfel, prima jumătate a anului 2021 poate fi caracterizată prin reluarea activității economiei mondiale în condițiile apariției unor probleme post-pandemice care reprezintă noi provocări pentru economia mondială.

Cea mai evidentă și, totodată, dificilă provocare este creșterea semnificativă a prețurilor, în mare parte asociată factorilor de ofertă. Această situație pune în dificultate continuarea promovării politicilor stimulative pentru redresarea cererii de consum.

În Raportul asupra inflației, numărul 3, din august 2021, elaborat de Banca Naţională a Moldovei (BNM), este indicat că, pe plan internațional, reacțiile autorităților monetare sunt dispersate, unii preferând continuarea retoricii privind caracterul de scurta durată al creșterii presiunilor pro-inflaționiste, iar alții acționând determinant pentru reducerea stimulării monetare sau chiar înăsprirea condițiilor monetare.

În acest context, Banca Naţională a Moldovei consideră că o țintă joasă, relativ stabilă și credibilă a inflației:

- va menține ratele nominale ale dobânzii la un nivel redus, care vor stimula investițiile pe termen lung și vor permite păstrarea competitivității agenților economici pe plan intern şi extern;

- va descuraja activitățile speculative şi va consolida stabilitatea financiară;

- va sprijini creșterea economică de durată, crearea locurilor de muncă şi va duce la creșterea productivității, ceea ce va îmbunătăți calitatea vieții populaţiei;

- $\quad$ va proteja populația cu venituri fixe şi păturile social-vulnerabile, care sunt afectate în special de rata înaltă a inflației prin erodarea veniturilor din investiții şi a plăților sociale (pensii, indemnizații etc.).

Pentru a răspunde la întrebarea dacă creșterea prețurilor este suficient de redusă şi stabilă de la o perioadă la alta este necesar a folosi un mecanism care ar cuantifica fluctuațiile prețurilor fie ca acestea s-ar modifica în sensul creșterii sau al scăderii.

Inflația şi deflația reprezintă fenomene economice importante, care pot avea consecințe negative asupra economiei. În esență, inflația este definită ca o creștere generală a prețurilor mărfurilor şi serviciilor pe o perioadă îndelungată, care conduce la scăderea valorii banilor şi, prin urmare, a puterii de cumpărare a acestora.

Deflația este de cele mai multe ori definită ca fenomen opus inflației, şi anume ca situația în care se înregistrează o scădere generală a prețurilor pe o perioadă îndelungată.

Situația când rata inflației este foarte înaltă şi/sau creste în mod constant, fiind imposibil realizarea controlului acesteia, este numită hiperinflație. Din punct 
de vedere social-economic, hiperinflaţia este un fenomen deformator, cu consecinţe ample asupra populaţiei, societății și economiei naționale în ansamblu.

$\mathrm{Nu}$ există o definiţie unanim acceptată a hiperinflației. Totuşi majoritatea cercetătorilor consideră hiperinflația ca fiind o situație în care rata lunară a inflației depăşește $50 \%$.

Hiperinflația, de regulă, are la originea sa decizia guvernului țării de a acoperi deficitul bugetar prin emisiune a banilor fără acoperire. Finanțarea monetară a deficitului bugetar presupune crearea unei cantități suplimentare de monedă, pentru a servi drept venit extraordinar a statului, pentru finanțarea cheltuielilor publice.

Consecințele grave ale acoperirii deficitului bugetar prin emisia excedentară de monedă au făcut ca această metodă de acoperire a deficitului bugetar sa fie abandonata, cel puțin în plan conceptual.

În pofida impactului său profund destabilizator, unele tari au continuat să aplice emisiunea inflaționistă de moneda, însă nu în mod direct, prin solicitarea sumei de la banca de emisiune, ci mai ales indirect, prin acoperirea soldurilor de casa negative cu împrumuturi de la banca centrală.

Hiperinflația poate fi condiționată și de așa numita cerere de tragere. Se înregistrează atunci când apare o creștere a cererii de consum care întrece oferta, influențând majorarea prețurilor. Consumatorii dacă sunt panicați și se așteaptă la o inflație continuă, cumpără mai mult acum pentru a evita să plătească mai târziu un preț mai mare. Această cerere excesivă agravează inflația. Este și mai rău dacă consumatorii stochează bunuri și creează lipsuri a acestora pe piaţă.

Putem afirma cu certitudine că politica monetară influențează decisiv nivelul prețurilor, respectiv stabilitatea acestora în timp. În cercurile economice, este unanim acceptat faptul că, pe termen lung, modificarea volumului de numerar furnizat de banca centrală, în condițiile în care toți ceilalți factori se mențin constanți, va determina doar variația nivelului general al prețurilor, şi nu modificări permanente ale unor variabile reale, cum ar fi producția sau şomajul.

Pentru promovarea unei politici monetare stimulative, capabile să asigure un nivel acceptabil de stabilitate a prețurilor, BNM utilizează următoarele instrumente de politică monetară:
- Politica ratelor dobânzilor;

- $\quad$ Operațiunile de piaţa monetară:

- Vânzări de certificate ale BNM;

- Operațiuni repo;

- $\quad$ Facilitățile permanente;

- $\quad$ Rezervele obligatorii;

- Piața monetară interbancară;

- $\quad$ Interventiiile pe piața valutară internă.

Banca Centrală Europeană (BCE), care este banca centrală a Uniunii Europene, cu funcția de administrare a politicii monetare în cele 19 țări care folosesc euro ca monedă, la fel are ca obiectiv major stabilitatea prețurilor.

Stabilitatea prețurilor reprezintă scopul principal al Eurosistemului. Consiliul guvernatorilor BCE a definit stabilitatea prețurilor ca fiind o creștere anuală a IPC pentru zona euro sub nivelul de $2 \%$. De asemenea, a precizat că, prin această definiţie, intenționează să menţină rata anuală a inflației la un nivel inferior, dar apropiat de $2 \%$, pe termen mediu [4].

Concluzii. Astfel ajungem la concluzia că instabilitatea prețurilor poate fi considerată, în general, fenomen cu consecințe nedorite. Există costuri şi dezavantaje substanţiale legate de instabilitatea prețurilor.

Deopotrivă, stabilitatea prețurilor împiedică majorarea acestor costuri şi aduce avantaje importante pentru toți membrii societăţii. Există mai multe modalităţi prin care stabilitatea prețurilor contribuie la atingerea unor niveluri ridicate de prosperitate economică, cum ar fi micşorarea ratei șomajului, sporirea nivelului de trai, etc.

Beneficiile rezultate din stabilitatea prețurilor sunt multiple și au efect direct asupra bunăstării populației și permit dezvoltarea durabilă a economiei naționale, deoarece stabilitatea prețurilor:

- $\quad$ conduce la consolidarea încrederii populației în politica statului și a băncii centrale, astfel obiectivele autorităților devin mai viabile, iar deciziile de politică monetară mai eficiente;

- $\quad$ asigură evitarea situațiilor de incertitudine privind evoluția prețurilor în viitorul apropiat, ceea ce permite cetățenilor un mod rațional de comportare bazat pe economisire și realizare a proiectelor investiționale.

\section{Referințe bibliografice:}

1. https://statistica.gov.md. (vizitat 11.09.2021).

2. https://insse.ro/cms/sites/default/files/field/publicatii/buletin_statistic_de_preturi_nr08_1.pdf.(vizitat 29.09.2021).

3. https://www.bnm.md/files/RI_3_august_2021.pdf. (vizitat 21.09.2021).

4. https://www.ecb.europa.eu/pub/pdf/other/whypricestability_ro.pdf. (vizitat 11.10.2021). 